\title{
Enhancing and Displacing Literacy Practices: Examining Student Publishing in a Fifth Grade Writer's Workshop
}

\author{
KIMBERLY LENTERS \\ The University of Calgary
}

\begin{abstract}
Publication of student work has been considered a mainstay of the writer's workshop since the early days of the 'children as authors' movement (Graves, 1983). However, this philosophy, which stipulates students should share their work with peers, may not be one that always benefits students. This case study utilizes the concept of literacy-in-action (Brandt \& Clinton, 2002), to look at the manner in which one local rendition of writer's workshop both enhanced and displaced student literacy practices. The guiding question asks: How are focal students, Sara, Ally and Nigel, engaging in the practice of publication of their writing and how are those publications, as literacy objects, mediating their practice of literacy in the writer's workshop? The examination of writer's workshop first presents the way publication of student writing found its way into Sara and Nigel's classroom and the kinds of investments accumulated in it as it made its way into their practice of classroom writing. It then presents the agentful activity engaged in by these students in their classroom literacy practice of writing for publication. Through the analysis, the ways an assessment-focused writer's workshop worked to enhance and displace individual student's literacy practices are brought out.
\end{abstract}

... if you give students an audience, other than teachers, their writing samples go way up. Their expectations on themselves go way up because they know their friends are going to be reading it.

(Ms. Wynn, fifth grade teacher)

Publication of student writing has been considered a mainstay of the writer's workshop since the early days of the 'children as authors' movement (Graves, 1983). Pedagogy associated with this movement sought to set up contexts in which young writers could engage in the same types of authentic processes utilized by professional writers (Murray, 1980) and to expand the types of audiences for whom students write (Graves, 1983; Langer \& Applebee, 1987). Early proponents viewed the process of writing as the primary focus of writer's workshop, while maintaining that children should be encouraged to draft and re-draft some of their written work with a particular audience in mind (Atwell, 1987; Calkins, 1986; Graves, 1983). At the elementary school level, this came to be used as a motivational device: students would be more willing to revise and polish their written work if they knew it was going to be put on display (Calkins, 1986, 1994).

Over the years, others have contributed to refining the use of writer's workshop in elementary classrooms (e.g., Buckner, 2005; Fletcher \& Portalupi, 1998; Ray, 1996). 
However, the essential format of draft and revise with the intention of presenting or publishing the work has remained. But does this time-honoured tradition of publishing their writing for an audience of peers always benefit students in the ways we imagine?

Lensmire (1994) provides an important study regarding the expectation that writer's workshop, as a pedagogical tool developed for use with middle class learners, should be successful across the spectrum of classrooms in North America. He looked at writer's workshop through a sociocultural lens to provide an examination of students' social positioning in the writer's workshop. Lensmire's analysis shows that positive aspects of his students' participation in writer's workshop were threatened by the way publications were used by some students to hurt others or express violent intentions, further entrenching existing social divisions and tensions in their classroom.

Although Lensmire's research provides important insights into the teacher's guiding role to ensure students are not negatively positioned by the publications of their peers, this article explores the ways student publications have consequences for their very authors. Utilizing the concept of literacy-in-action (Brandt \& Clinton, 2002), I look at the manner in which practices associated with one local rendition of writer's workshop, both enhanced and displaced student authors' literacy practices. More broadly, the inquiry also examines the way curricular innovations, applied to widely used pedagogical tools, work to enhance and displace student literacy practices. I use the following questions to shape the inquiry: How did the practice of student publication arrive in the fifth grade class of one elementary school? How are three students in this class, Sara, Ally, and Nigel, engaging in the practice of publication of their writing? How are those publications, along with other literacy objects and actors associated with the writer's workshop, mediating Sara, Ally, and Nigel's practice of literacy in the writer's workshop? Taken together, the findings generated by these questions form a snapshot of people, objects, and practices at work to produce a writer's workshop in which publication of student work both enhances and displaces student writing practices.

\section{Considering Materiality in Classroom Literacy Practices}

Sociocultural perspectives view literacy as a social practice, an activity associated with social action and mediated by that action. This ideological perspective stands in contrast to an autonomous model, in which literacy is seen as a set of discrete skills (Street, 1993). In an ideological model, individuals and communities' particular uses of literacy and their agency in that activity are highlighted (e.g., Barton, Hamilton, \& Ivanic, 2000; Heath, 1983; Scollon \& Scollon, 1981; Scribner \& Cole, 1981; Street, 1993).

The social practice understanding of literacy has led to important insights into the many ways people use literacy for everyday practices, often in ways that are particular to themselves as individuals or to their communities. In recent years, however, social practice scholars have noted that the focus on everyday literacies may not adequately account for all that is taking place at local sites of literate practice (Bayhnam \& Prinsloo, 2009; Brandt \& Clinton, 2002; Collins \& Blot, 2003; Lewis, Enciso, \& Moje, 2007; Street, 2003). As Brandt and Clinton argue, the ideological model may exaggerate "the power of local contexts to set or reveal the forms and meanings that literacy takes" ( $p$. 338). Individuals and communities do not always have complete control over the forms of literacy they practice and more often than not, the literacies people practice do not originate in their local communities. This is particularly true in the practice of classroom 
literacies. Furthermore, one of the outcomes of understanding literacy through an ideological model is the tendency to privilege human activity and bracket off the fact that human interactions with literacy always involve objects and sometimes those objects play a role in the literacy people practice (Barton \& Hamilton, 2005; Brandt \& Clinton, 2002; Hamilton, 2001; Pahl \& Rowsell, 2006).

To address these concerns, Brandt and Clinton (2002) propose the concept of literacy-in-action to facilitate inquiry into the ways readers and writers are mediating their social world through their literate practice and how literacy is acting in the situation as a social agent. Following French sociologist, Bruno Latour, they argue for "opening the door between people and things in the accomplishment of literacy practices in order to understand their formal and functional interrelationships in various circumstances" ( $\mathrm{p}$. 348). Latour presents an alternative social theory in which he troubles the idea of "social explanation" as it is used by modern sociology (Latour, 1994, 1996, 2005). Latour proposes Actor-Network-Theory (ANT), a sociology of associations, which uses the concept of networks and an ethnographic approach to trace material and human resources in order to gain an understanding of social processes. Tools or objects are viewed as mediators, not merely symbolic expressions of groups and thus, there are many building blocks of the social world - human and non-human. The task in a sociology of associations, is to look at a group (a social aggregate of human actors and non-human actants) and interpret that world by tracing the associations made by the actors therein.

Latour (1996) labels the types of repeated social interactions in which human beings engage, such as shopping for food, withdrawing cash from a bank machine, or mailing a parcel, framed social interactions. Framed social interactions such as these, designed in global spaces and localized in countless local sites, are not only made possible by human action but also by the framing activity of the objects they put in place to allow the interactions to be taken up again and again without the presence of the specific individual(s) who designed them.

In this study, the writer's workshop is the framed social interaction under examination. It is an interaction of actors, objects, and practices, first conceived in local classrooms in New England (Graves, 1983) and further theorized in academic circles (Atwell, 1987; Calkins, 1986), which is now localized to countless classroom sites thirty years after its conceptualization (Hoffman, 1998; Lipson, Mosenthal, Daniels, \& Woodside-Jiron, 2000). The actors and the objects are immediately recognizable as those conceptualized at global, academic sites; however, as the study will demonstrate, the practices that are generated at the local level provide interesting points of departure in the meanings produced.

In literacy-in-action (Brandt \& Clinton, 2002), the objects brought into focus in framed social interactions are termed literacy objects. Human actors are understood to assign responsibilities to literacy objects, often resulting in a literacy object carrying a degree of authority and power. In this article, I employ one Brandt and Clinton's proposed constructs, the notion of sponsors of literacy. Sponsors of literacy are agents, human or non-human, who "enable or induce literacy" (p. 350). The concept of sponsors of literacy recognizes the fact that "literacy practices are rarely invented or sustained by local agents alone" (p. 350). Sponsors of literacy frequently use literacy objects to serve as their surrogates; this delegation of responsibility often has an enhancing or displacing effect on literacy practices. 


\begin{abstract}
Method
Writer's Workshop in a Local Classroom

In this article, I examine writer's workshop in a fifth grade classroom using ANT and its literacy studies application proposed in literacy-in-action. The middle-class, urban, fifth-grade classroom at Howe River Elementary was part of a blended fourth/fifth grade group of sixty students, team taught by two teachers. In this classroom, not unlike most areas of North America where accountability measures have been mandated, tensions between the demands of accountability and the progressive philosophies in which the teacher had been trained were evident, particularly in the area of Language Arts. For example, Ms. Wynn, the fifth grade teacher in the study, held the belief that student performance should be judged on an individual basis, but had to reconcile this belief with the requirement that she assess students and assign grades based on gradelevel benchmarks. Classroom conditions, such as a high student-teacher ratio, noise inherent to their school's open-concept building design, and the presence of several special needs students in the class, placed contextual pressures on students and Ms. Wynn. These pressures, when combined with Ms. Wynn's philosophy that the intermediate years were important years for developing student independence, produced a culture where adherence to classroom routines and teacher-set deadlines was prized.

Three focal students with unique and somewhat precarious social positioning in their classroom (Sara North, Ally Random, and Nigel Green), the fifth-grade teacher (Ms. Wynn), and Nigel's mother (Mrs. Green) (all pseudonyms), were the main participants in this study, which draws on data from a five month long case study on classroom literacy practices.
\end{abstract}

\title{
Data Collection and Analysis
}

For this article, I use three data sources: observations; interviews; and documents. The data is taken primarily from a six week period of time, just after the class had been introduced to writer's workshop, when the students were engaging in their first draftrevise-publish cycle.

An important aspect of literacy-in-action is the notion that local literacy practices are not isolated but always shaped, to some extent, in distant or global spaces. Thus a network may be traced from local uses of literacy to the sponsors of many of those practices "located" in distant spaces. In the first stage of analysis, I looked at the resources Ms. Wynn reported as helpful for constructing the writer's workshop in her classroom. Through this analysis, I was able to identify the sponsors, practices, and objects traditionally associated with writer's workshop as a framed social interaction in distant spaces, their traces in this classroom, and the practices and objects layered on there. In the second stage of analysis, I focused on examining the practice of publishing student writing and employed the unit of analysis, literacy-in-action (Brandt \& Clinton), with its dual focus of examining the agency of human actors in the practice of literacy and scrutinizing the mediating influence of literacy objects in the activity. These two stages of analysis enabled me to trace the network of actors, human and non-human sponsors that mediated Sara, Ally, and Nigel's practices of literacy in their classroom's writer's workshop. 


\section{Writer's Workshop in Local and Global Sites}

Distant Sponsorship of the Writer's Workshop

How did the practice of student publication arrive in the fifth grade class of one elementary school? In this section, I follow the traces that connect the writer's workshop in the fifth grade classroom at Howe River Elementary to the global spaces in which they were first introduced. Through this analytical move, the contributions of many sponsors of literacy to the local rendition of writer's workshop become apparent. Figure 1 maps the complex network of human actors and non-human actants that mediated the format the framed social interaction took in this fifth grade classroom. In short, Ms. Wynn's decisions around how to format writer's workshop were influenced by her reading of the work of Donald Graves (1983), Lucy Calkins (1994) and Aimee Buckner (2005), introduced to her through a graduate level course in writing instruction and a school board professional development reading club. She was also guided by her understanding of the curriculum for the province in which she taught (British Columbia Ministry of Education, 2002, 2006). 


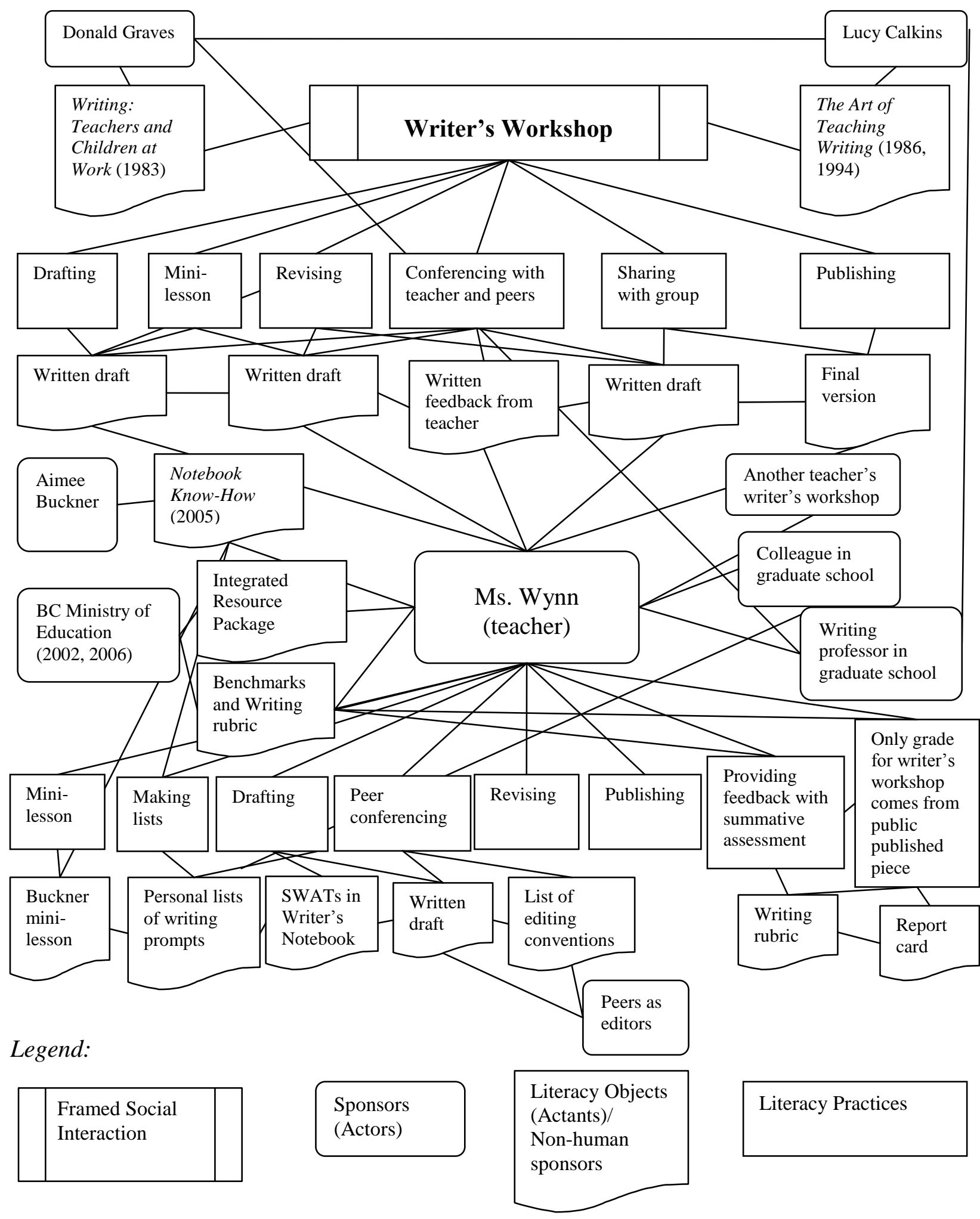

Figure 1. The actor-network mediating the writer's workshop in which Sara, Ally, and Nigel participated.

People, Practices and Objects Associated with this Fifth Grade Writer's Workshop 
In the fifth grade writer's workshop at Howe River Elementary, practices of teacher-provided mini-lessons and student-drafting, -revising, -conferencing and publishing were present. Some of the literacy objects traditionally associated with writer's workshop as set out by sponsors such as Graves, Calkins and the BC Ministry of Education - rough drafts of student writing and final published pieces - were also present. However, the addition of new practices and literacy objects and omission of others altered the balance this rendering of writer's workshop took in comparison to the traditional writer's workshop. In this section, I explore the transformation of practices by Nigel, Ally, and Sara's classroom sponsor of literacy, Ms. Wynn.

In the following quote, Ms. Wynn describes the ideas that inform her rendition of writer's workshop.

Last year, I had learned in a workshop something from [a district-wide literacy project], I think that if you give students an audience, other than teachers, their writing samples go way up. Their expectations on themselves go way up because they know their friends are going to be reading it. And so last year, I created this idea that there's this binder. And once there's work in the binder you can sign it out and you can read what other people write. And so this year we decided to incorporate that with this new book [Notebook Know-How (Buckner, 2005)]. (Ms. Wynn)

Publication of student writing was a practice Ms. Wynn had the year before adopted in her classroom, believing it would increase the amount of finished work her students would produce and the quality of that work. It was a practice on which she overlaid other sets of practices. One of these sets of practices revolved around the use of a writer's notebook. During the year in which the study took place, Ms. Wynn participated in a school district sponsored teacher book club, which was studying the teacher-practitioner text, Notebook Know-How (Buckner, 2005). Here Ms. Wynn elaborates on ideas she garnered from the text:

[Notebook Know-How] is good in that it really does teach you this whole idea as teachers, like, don't give a prompt. Have the students come up with their own prompts: have them come up with their best memories or worst memories; things that they wonder about; lifting a line from one story to another to just start a new story.

One idea Ms. Wynn picked up from the text was the notion that the kinds of story prompts she had used in the past may not have encouraged the kind of productive writing she hoped to see in writer's workshop. Ms. Wynn, borrowing on Buckner's work, had students create lists such as "my best memories," "my worst memories," and "things that make me go hmmm" in their writer's notebooks. She then had students engage in another practice she had learned from a fellow student in her graduate level course on writing instruction. This practice, known as SWAT (Sustained Writing All the Time) was added to the personal-prompt-list practice. Students were to choose an item from their personal prompt lists and write about it continuously for seven minutes in their writer's notebook. 
Once a few "SWATs" were generated, students were given ideas for turning these rough pieces of writing into more refined pieces through mini-lessons taken directly from the Buckner text.

Based on past experiences, Ms. Wynn felt that writer's workshop could very easily be a "free-for-all" and that structure was necessary in order to help students produce work that could be published. She elaborated,

And so we're trying to make some freedom in there without it being too free. I've been part of a writer's workshop before where I've taken over somebody else's program. And that was interesting because that was a total free-for-all. The students could pick anything. They could write about anything and at the time Lord of the Rings was really big and ... for about six or seven boys all they wanted to do was write these Lord of the Rings adventures, but they were never they were never completed. They were all to be continued. Like they were never they were just like a little - and they were never really all that great to be honest.

Mini-lessons from Notebook Know-How were used to fulfill this structure requirement, along with an expectation that students be at certain stages of the draft-revise cycle at certain times and set whole-class publishing dates.

Another set of practices and literacy objects added to the traditional writer's workshop in the fifth grade classroom is associated with assessment. Required to assess student writing using provincial benchmarks, Ms. Wynn graded the students' publications using the rubric provided by the provincial ministry of education. The necessity of grading and the press of time worked together to produce the following practice: rather than reading student drafts along the way and providing feedback for their writing that would help them revise that writing, Ms. Wynn provided feedback after a piece was published. This feedback took the form of a photocopy of the writing rubric with sections highlighted, showing which criteria were met. In order to ensure what she was grading was actually student work, she elected not to offer feedback along the way. However, knowing students require feedback prior to publishing their work, she had the students engage in a peer-editing session in which two peers would look at a student's piece of writing and offer written suggestions. In this way, students received no formative feedback on their writing from their teacher. The only grade students received for the writer's workshop portion of their language arts grade were the grades they received on published pieces. The procedures she set up in the first cycle of this writer's workshop were followed by Ms. Wynn throughout the rest of the school year, that is, through three subsequent draft, revise, publish cycles.

The overall thrust of the writer's workshop in this classroom can be said to be an orientation toward the production of finished pieces of writing, published for the student authors' peers and for the purpose of providing gradable material for their report cards. Table 1 provides a synopsis of the preceding analysis, outlining the objects and practices associated with writer's workshop across the global spaces connected to this local classroom. Understanding the way writer's workshop was constructed in this classroom provides important contextual information necessary for examining the way people, practices, and objects associated with it worked to mediate Sara, Ally, and Nigels's classroom writing practices. 
Table 1. Objects and Practices Associated with the Local-Global Writer's Workshop Writer's Workshop in the Fifth Grade Classroom

\begin{tabular}{|c|c|}
\hline $\begin{array}{l}\text { Practices traditionally associated } \\
\text { and introduced to Ms. Wynn in a } \\
\text { graduate course on writing } \\
\text { instruction } \\
\text { (Sponsors: Calkins, 1986, 1994; } \\
\text { Graves, 1983; professor in } \\
\text { graduate writing course) }\end{array}$ & $\begin{array}{l}\text { Daily writing time } \\
\text { Drafting and revising } \\
\text { Conferencing with peers but most importantly, } \\
\text { with the teacher } \\
\text { Publishing revised drafts for others to read } \\
\text { Orally sharing work (drafts or publications) with } \\
\text { groups of students }\end{array}$ \\
\hline $\begin{array}{l}\text { Practices added/adapted in this } \\
\text { classroom } \\
\text { (Sponsors: BC Ministry of } \\
\text { Education, 2002, 2006; Buckner, } \\
\text { 2005; colleague in writing course; } \\
\text { another teacher in whose class } \\
\text { Ms. Wynn once taught) }\end{array}$ & $\begin{array}{l}\text { Using a writer's notebook (Buckner, 2005) } \\
\text { Mini-lessons prior to bi-weekly half-hour writing } \\
\text { sessions (Buckner, 2005) } \\
\text { Sustained Writing All the Time (SWAT) for } \\
\text { drafting } \\
\text { Formative assessment in form of a peer-editing } \\
\text { session } \\
\text { All publications held in a classroom binder } \\
\text { All teacher feedback given after publication } \\
\text { Grading publications according to provincial } \\
\text { benchmarks }\end{array}$ \\
\hline $\begin{array}{l}\text { Objects associated with Writer's } \\
\text { Workshop in this classroom }\end{array}$ & $\begin{array}{ll}\text { Mini-lessons taken from Notebook Know-How } \\
\text { (Buckner, 2005) } \\
\text { Writer's notebook with personal lists for writing } \\
\text { prompts and SWATs } \\
\text {. } & \text { Rough drafts } \\
\text {. } & \text { List of writing conventions } \\
\text {. } & \text { Student publications } \\
\text {. } & \text { Story starter flip book (Nigel) } \\
\text {. } & \text { Classrinished homework board } \\
& \text { publications } \\
\text {. } & \text { Grading rubric for teacher feedback } \\
\text {. } & \text { Report cards }\end{array}$ \\
\hline Practices and objects missing & $\begin{array}{l}\text { Daily writing time } \\
\text { Teacher conferencing } \\
\text { Written feedback from teacher through the } \\
\text { drafting phase } \\
\text { Oral sharing of drafts and publications }\end{array}$ \\
\hline
\end{tabular}

Three Students and the Practice of Publishing in the Writer's Workshop

Ms. Wynn viewed writer's workshop as an opportunity to help her students learn "there are no boundaries to writing"; however, the responsibilities delegated to student publications and her removal of herself from certain aspects of the writing process in this 
classroom may have worked at cross-purposes to this aspiration. In this section, I look at how three students in this class, Sara, Ally, and Nigel, engaged in the practice of publication of their writing. To accomplish this, I look at the way the people, practices, and literacy objects associated with the writer's workshop in the fifth grade classroom, elaborated above, interacted with each other to mediate Sara, Ally, and Nigel's literacy practices. After introducing the student, I follow the traces of their story writing over their first draft, revise, publish cycle.

\section{Sara - Starting out as a "Reluctant" Writer}

Sara was a bright and engaging young adolescent. In discussions with her, I often noted how mature and confident Sara seemed in the way she related to me, conversing as though she were a fellow adult. At the beginning of the school year, Sara's mother related concern to me regarding Sara's lack of significant friendships at school. By the beginning of second term, Sara, a fifth grade student, had established a place in group of girls in the fourth grade portion of the class and soon began to spend time daily in MSN chat rooms with them. She enjoyed playing videogames on her handheld gaming device or with her brother, when he would allow her to play on his larger gaming system. She also loved to watch television and named the adult sitcom, Friends, as her favourite show. Sara was passionate about horses; she took riding lessons once a week and went to the stables on Sundays to help with the horses in exchange for her riding lessons.

Sara's mother reported that Sara had experienced difficulty with reading and writing from her earliest years. However, it had been a frustrating and difficult endeavour to get her tested for a learning disability and even more difficult to secure extra support for Sara at school once that diagnosis was made. Sara worked diligently during the writer's workshop: always at her desk, attempting to write for the whole of the period that was to be used for uninterrupted writing. While she was seriously interested in engaging with the writing process as it was set out in her classroom, some of the literacy practices objects (writer's notebook, story drafts) seemed to fit well with Sara's writing practice and some of them appeared to be of little consequence (mini-lessons, student annotations on her draft horse story). However, Sara struggled with the literacy object, student publication, and it, in turn, served to displace some of her already tenuous literacy practices.

Displacing interactions. The chain of story writing instances in which Sara participated following her teacher's announcement of the first publication deadline illustrates the negotiations Sara made. As she tried out certain genres in response to the competing demands she perceived to be associated with the piece she would publish, Sara's writer's notebook and ultimate publication provide traces of the decisions she made. These instances also document the kinds of displacement of literacy practices Sara experienced as she participated in the practice of student publication. In the space of time between the class being told to prepare a piece of writing for publication in the Classroom Binder and her final choice regarding what to publish (two weeks), Sara drafted four pieces, working to come up with something she could make public. She started with a story she labelled, "kind of true and kind of false" (a hybrid genre that Sara described as her preferred mode for writing). In this unedited piece, Sara semi-autobiographically tells the story of a girl who is unhappy with her weight. 
Once upon a time there lived a kinda fat girl who never had any friends. She always ate all alone and never played with someone. So one day she decided to lose some weight so she told her mom. So that night her mom stayed up all night looking and looking. Then she found something called Shape down. So then the next morning the mother rushed to go tell the daughter. Then the daughter was ecstatic so she and her mom went everyday and she lost 5 pounds. Ever since that day she has never felt sad about the way she was shaped. She always had friends. The end

By Sara

Subsequently, she started a fictional piece:

Once upon a time there lived a girl who had everything she need money jewels and did I mention money. Well yes she did indeed have lots of money. She grew up with everything lots and lots of money. But one day

Sara did not finish this draft.

Then, in a third instance, she returned to her original semi-autobiographical piece, likely trying to refine it for publication:

Once upon a time there lived a different shaped girl. She never had any friends and no one ever ask her to come

After these two lines, Sara abandoned the story. In the end, she decided to publish a piece she had previously written. It is titled "Why Do Horses Buck?" (Figure 2). In this more factually-oriented piece, Sara used her knowledge of horses and horseback riding to respond to the question posed in her title. 


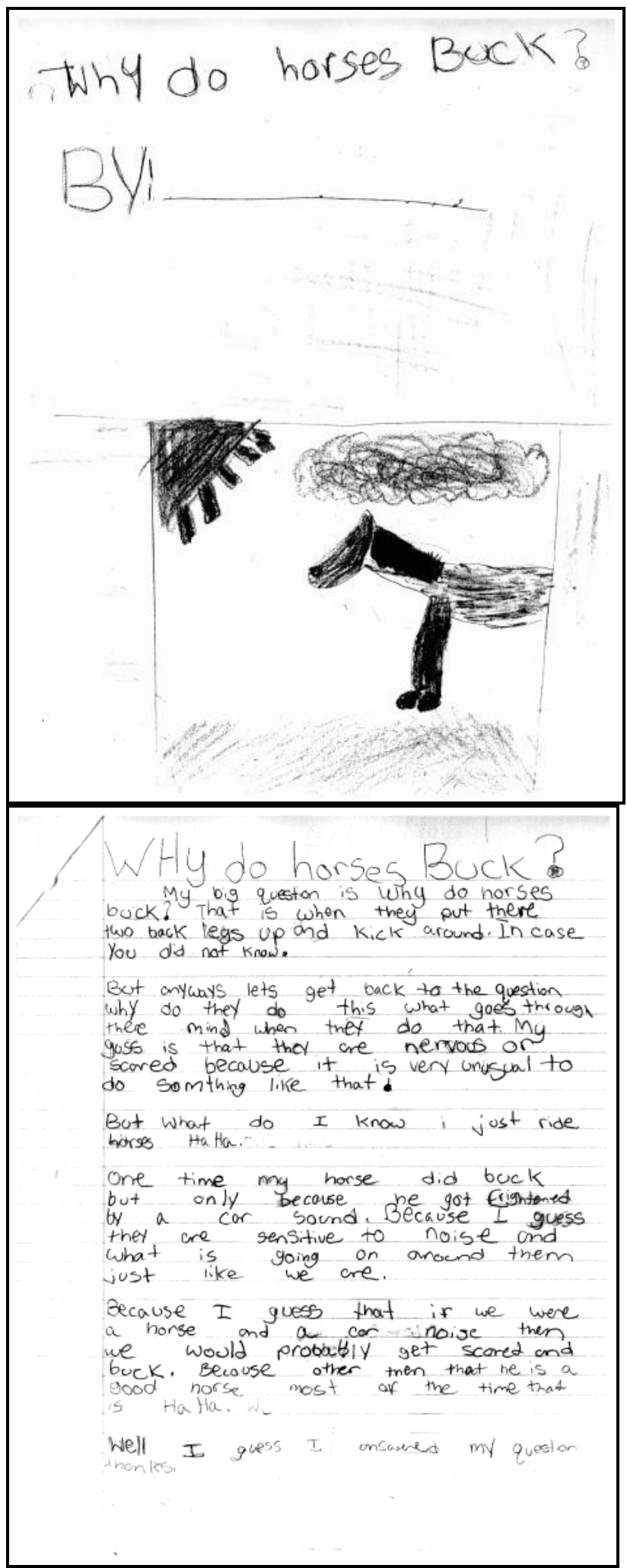

Figure 2. Sara's first published piece from the fifth grade writer's workshop Transcribed, Sara's story reads as follows: 
WHy do horses Buck?

My big question is why do horses buck? That is when they put there two back legs up and kick around. In case you did not know.

But anyways lets get back to the question why do they do this what goos through there mind when they do that. My guss is that they are nervous or scared because it is very unusual to do something like that!

But what do I know i just ride horses. Ha Ha.

One time my horse did buck but only because he got frightened by a car sound. Because I guess they are sensitive to noise and what is going on around them just like we are.

Because I guess if we were a horse and a car noise then we would probably get scared and buck. Because other then that he is a good horse most of the time that is. Ha Ha.

Well I guess I answered my queston thanks.

Publishing with consequence. Sara was keenly aware that publication of her work came with certain consequences. It appears that as the injunction to have a piece published by a given date loomed. Sara tried out different genres, searching for a way she could produce the kind of piece she wanted to publish - an autobiographical story with embellishments. However, once Sara decided this kind of story would be too personal, she had a further social hurdle to negotiate. In her pursuit of a piece that would be acceptable to her friends she was concerned that the kind of writing she made public in the Classroom Binder was not the kind of piece her peers were publishing. In the following, I had just asked her what was going to happen with the pieces the class had peer-edited that day and Sara expressed her concern that her peers might view her piece negatively.

Sara: Probably it will get published for our first actual, actual draft. And then we'll do another one and another one.

KL: And where are they going to go...

Sara: They're going to go in the [classroom] book. So our writing is gonna get the [classroom] binder is bam! empty! But now... it's gonna be full of our first drafts!

With this enthusiastic description of the binder that was to contain the students' published pieces, I assumed Sara looked forward to the prospect of making her work public and asked:

KL: Are you excited to have other people read your work?

Sara: [pause] Mmm... [shaking head] 
KL: No?

Sara: 'Cause I know that people won't think, 'Oh my god, Sara's is just the worst.' Or, 'Oh my god, what's her problem? She's writing about a horse bucking last Sunday'.... But to some people it would be [the worst].

As a student with a designated reading disability, making her work public wasn't always easy for Sara. However, Sara was at a stage where she wanted to try working independently. She was proud of the fact that she had completed the horse piece by herself, without the assistance of her private tutor or the school resource teacher, with whom she worked once a week. She said, "Like I got mine done, like four days before and had it handed in. Like even, I didn't tell my tutor I was doing it, because I wanted to do it myself." However, might not the consequences of making public a piece that has errors of punctuation, spelling, and syntax, counteract the self-efficacy she felt with having independently completed the work ahead of the deadline.

Sara also worried her peers might find her topic out of step with their own. She stated:

Sara: Yeah. Me and my friends said we're gonna read all of our drafts together. And I'm like, 'Heh heh heh,' 'cause they all write about princesses and stuff. [laughs]

KL: And that's not your thing?

Sara: Or they all write about boys and I'm like, 'Yeah, no!' [laughs] I'm not in that stage yet.

Sara and her friends had planned in advance to sit together to read their newly published pieces and she was unsure of their reactions. Her "Heh, heh, heh" was a dramatized, embarrassed laugh, expressed with her hand covering her mouth, as she anticipated their judgment that her story was not as mature as theirs. Sara had previously told me: "I've always wanted to write a story about princesses" and her draft story of the girl with "lots and lots of money" may have been her attempt to do so. This aspiration did not materialize in her published writing, however.

Sara was not the only student who viewed publication with a certain amount of trepidation. Ally also had serious reservations about publishing for an audience of her peers.

\section{Ally-Starting out as an "Avid" Writer}

In contrast to Sara, Ally's demeanour was somewhat more watchful. This reserved stance, along with her observations regarding school and family life, suggests an introspective nature. Ally often found herself caught between two different groups of friends and struggled to maintain allegiances to one group without offending the other. Outside of school, Ally took dance lessons, enjoyed doing handcrafts with her friends, played with her new dog and liked to draw. Ally took her schoolwork very seriously and was eager to please her teachers with her work and compliance with classroom protocol. She reported that she really did not like reading as it was set up at school because she felt much of what she was asked to read was boring or too difficult. She also commented that she felt that over the years with her experiences in levelled reading groups, reading in 
school was too competitive. Ally loved to write and kept a personal diary at home. At school, her journals, reports, and stories often employed a conversational voice and personal details. On her report cards for the two reporting periods in which I observed in her classroom, Ally was rated as "Meeting" and "Fully Meeting" grade level expectations in Language Arts. Ally exceeded expectations in drama, and indeed, demonstrated a dramatic flair on the occasions I observed her participation in dramatic productions.

Displacing interactions. In this first interview excerpt, Ally and I were talking about the writing process the class had just been through together as they published their first pieces. She showed me the story and cover page she was just completing. I wanted to know what would happen with everyone's stories, once they were placed in the Classroom Binder:

KL: So then what will happen with that binder?

Ally: People can read it.

KL: Oh nice.

Ally: I don't really want people to read it though.

KL: Oh. Because...

Ally: I don't like people reading my - my stuff.

KL: Because you feel shy? Or...

Ally: No, I just don't - like they - 'cause I go to the same school and I'm in the same class and I - yeah. And I don't really like people like looking at my stuff sort of. It's kind of like - sometimes it's kind of private and stuff. And so - yeah.

KL: Do kids - do they comment on things?

Ally: That's what I'm kind of worried about, yeah.

KL: So does that influence what you write about?

Ally: Them?

KL: Like for the binder. Do you try to write something that's not as personal because of that?

Ally: Yeah.

In this conversation, Ally surprised me with her concern about people reading her work. In previous discussions she told me that she loves to write because through writing she could express her imagination.

The entries in Ally's writer's notebook, made previous to the teachers' announcement of a publication due date, were more numerous than Sara's. What made Ally decide to choose the very first piece she had written in her writer's notebook rather than subsequent pieces? Looking at some of her drafts provides insight into this question.

All of the pieces in her writer's notebook were accounts of events in her life. Included in these accounts were expressions of some very personal and deep feelings. For example, she began writing one account of Christmas dinner,

This Christmas was very fun but also disappointing. I had a kind of unusual dinner because instead of turkey we had ribs. My whole family loves the way ribs are covered in bbq sauce. The BBQ sauce makes it taste like heaven because when you see the ribs they look just so tasty you cannot believe your eyes. 
She crossed this account out and then wrote:

This Christmas was fun but also kind of disappointing. Christmas was fun, but I feel bad though because kids in other places in the world didn't get what I got. Also I feel like sometimes I can hear them and I feel bad. But my mom says to just pray and that it is not my fault.

But now I'll talk about everything else! I was so excited (even though I did not want to be). When I saw my presents I could not believe I was feeling them. And the taste of the chocolate in my stocking tasted soo good. And I think that maybe THAT WAS THE BEST CHRISTMAS OF ALL!

On the day the students were given a publication deadline (first draft due in one week), Ally wrote a piece about her new dog. The students had been told on that particular day that they could use the "lift a line" technique (Buckner, 2005, p. 30) Ms. Wynn had just demonstrated, or re-write a draft for publication, or start a new piece that they wanted to publish. Ally wrote a new piece:

I have a dog and his name is rusty and I love him because he is a good dog and he loves me too!

Things I taught him

- To Give Kisses

- To Dance

- To Hug

- To Sit

- To Drop it

- To Stay

Things I want him to learn

- To leave it

- To fetch

- To lay down

- To go away

- To stay without being on leash

The instruction the students were given for new drafts started that day was as follows: they were to be pieces they wished to publish in the Classroom Binder. Given her mindfulness of audience and that publishing certain pieces for her peers was potentially dangerous, had she started this piece because she felt it represented safe territory? Perhaps so, but when I inquired, Ally couldn't remember. However, Ally did not choose to publish this story. The majority of pieces her friends were preparing for publication in 


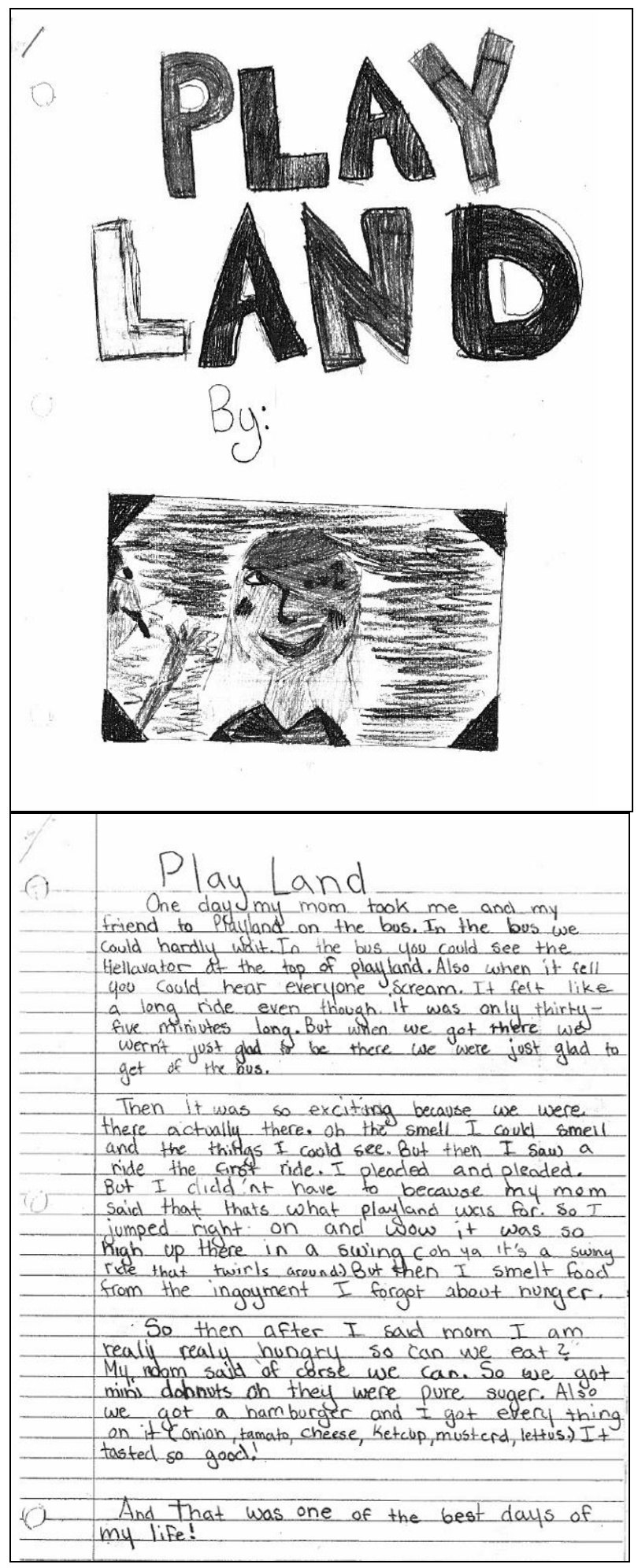

Figure 3. Ally's first published piece from the fifth grade writer's workshop

the Classroom Binder were fiction. Ally ultimately decided she would publish something that more closely resembled the story genre they were adopting, titled Play Land, a recount of a recent trip she had taken to a local amusement park (Figure 3). 
Publishing with consequence. My conversation with Ally regarding publishing makes apparent her concern for the particular audience for whom she was required to write. For Ally, writing was a highly personal endeavour in which she expressed deep emotion. Past experiences with students at her school had already taught her that her peers were often competitive and not always understanding of difference. The requirement that her private thoughts be put on display in publications intended for an audience of her peers, who are not always sympathetic readers, was most definitely a source of anxiety for Ally. The requirement played into her decisions regarding which pieces she was willing to polish for publication. Had Ally been given the option of writing for a different audience - her teacher or perhaps a more distant audience where she could keep her identity a secret-her investment in her polished-for-publication pieces of writing and the scope they took may well have been much deeper and more personally satisfying.

\section{Nigel -Starting out as a "Reluctant" Writer}

In the classroom, I observed Nigel to be an articulate and animated youth when talking about places he had been, movies he enjoyed, videogames he played or when involved in group projects. However, he appeared to be highly unengaged during group instruction and the majority of independent work periods. At the beginning of these periods, such as writer's workshop, he invariably signed himself out with different friends to use the washroom (the school had a policy that students were not allowed to use the washrooms without a buddy accompanying them for security purposes). He often spent ten to fifteen minutes there before returning to the classroom, where he spent the remaining time either chatting, watching his classmates, making humorous drawings in his homework planner, or reading. Nigel frequently commented that he had a lot of homework. Very proud of his sense of humour and the fact that his friends were appreciative of it, he told me that one of his favourite articles of clothing was a t-shirt that read, "Homework hurts the environment."

Nigel received a certain amount of classroom "attention" for his off-task behaviours. While he was neither hurtful, nor loud or overtly disrespectful in his activities, it did not go without notice by Ms. Wynn that he was generally off-task. Certain activities, such as long forays to the washroom or chatting quietly with neighbours during whole-group instructional periods, frequently earned Nigel a spot on the "Warnings" board in the classroom. However, he rarely got to the critical threewarnings-in-one-day stage, for which he would have to stay in for recess.

The classroom policy was that the fifth grade was a time for students to begin taking responsibility for their own work. Thus, all students were expected to stay on-task during independent work times, work was not checked on a day-to-day basis and parents were not immediately informed when students were not completing assignments. Thus, by the time mid-term reports were issued in the first term, Nigel's parents were surprised to learn of his classroom status as the humorous kid who did no work. Nigel's mother soon took charge of the situation and by late January, when the first publication date was announced, Nigel and his mother had settled into a routine where he was to bring home anything he had worked on during the day so that she could check it. At that point in time, Nigel was often spending three hours every day after school to complete work he 
had not done in class, along with the evening's assigned homework. It was against this backdrop that Nigel published the snowman story.

Enhancing encounters. Unlike Sara and Ally, Nigel's published work served to enhance his classroom literacy practices. His writer's notebook - notably short of entries compared to other classmates - the personal writing prompt lists in the notebook, and the looming report card, were literacy objects that provided little help to Nigel. Nigel had written two very short drafts before Ms. Wynn set the publishing date and nothing for three sessions that followed. When I asked about this, he told me he had very little in the notebook because he never had any good ideas. Nigel wrote the following during the class session in which the rest of his peers were engaging in a peer-editing session to ready their drafts for publication. His unedited, futuristic adventure story, Sled Ride, reads as follows:

I was sitting on top of everest on a tuesday January 5/5271 they made it easier to breath so there I was getting ready to go down the bunny hill on my sled so I started really slow and half way down I heard a huge crash. A huge pile of snow that was suposed to stop me from heading straight down the mountain where there are crevases every few feet that could crush your car just rolled away from me. Everyone's sled had brakes but the only problem was that I was using a 3000 year old sled with no brakes and I was heading right down the mountain. I hit a flashing piece of metal and I threw it at the cars and it blew up. I flew of the cliff and flew onto the highway and a car took me down the monton.

The intertextual links between the kinds of books Nigel loved to read (i.e., real-life adventure stories) and the story he drafted are salient in this piece. When Nigel's mother, Mrs. Green, read this draft - which, when read with punctuation mentally-inserted, has a clear structure to it-she felt the story was confusing. Here Mrs. Green describes the situation:

He has this mind full of all these funny things and bizarre things. But to get them organized and down on paper is so tough for him. So, he'd written a story and and you know he was getting more and more confused and it was getting more and more bizarre and so somebody gave us this little story starter. So, it's basically three phrases - three parts of a sentence and you just flip through it and you flip it to any combination. And for instance his was, "My teachers are - my new teacher, is a snow man, who lies all the time." So I said, "Okay, now take that..." And - so that gave him ideas. (Mrs. Green)

Nigel drafted My Teacher is a Snowman (Figure 3) on his own and, with his mother's editorial assistance, added details and clarifications to his first draft. He then completed a good copy, drafted a cover illustration, followed by the good copy of the cover page and placed the work in the Classroom Binder, just after the due date. 


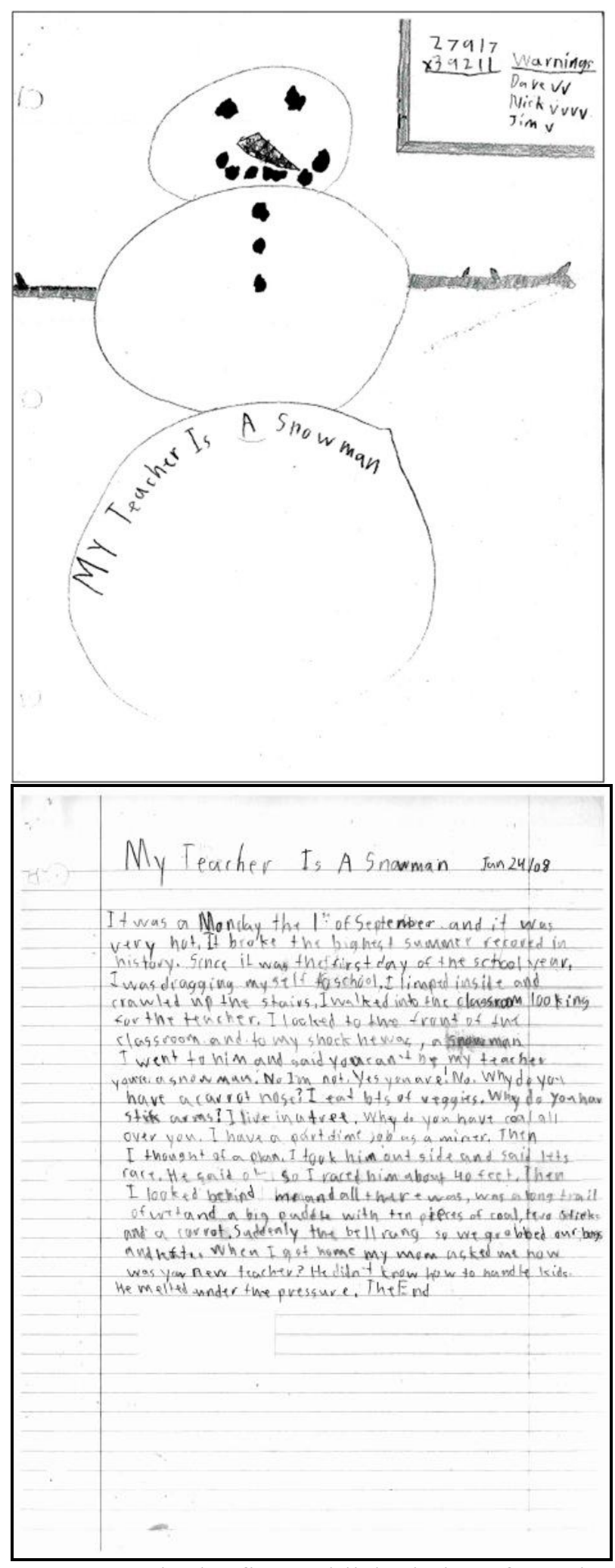

Figure 4. Nigel's first published piece from the fifth grade writer's workshop A transcription of Nigel's story reads as follows: 
It was Monday the $1^{\text {st }}$ of September and it was very hot. It broke the highest summer record in history. Since it was the first day of the school year, I was dragging myself to school. I limped inside and crawled up the stairs. I walked into the classroom looking for the teacher. I looked to the front of the classroom and to my shock he was a snowman. I went to him and said you can't be my teacher you're a snowman. No I'm not. Yes you are! No. Why do you have carrot nose? I eat lots of veggies. Why do you have stick arms? I live in a tree. Why do you have coal all over you. I have a part time job as a miner. Then I thought of a plan. I took him out side and said lets race. He said o.k. So I raced him about 40 feet. Then I looked behind me and all there was, was a long trail of wet and a big puddle with ten pieces of coal, two sticks and a carrot. Suddenly the bell rang so we grabbed our bags and left. When I got home my mom asked me how was your new teacher? He didn't know how to handle kids. He melted under the pressure. The End.

Publishing with consequence. The consequences of publication were qualitatively different for Nigel, in comparison to Sara and Ally. In the following excerpt from a conversation I had with Nigel, we were looking at work that was sitting on his desk and I asked about a drawing of a snowman.

Nigel: That is the front cover of a book I wrote.

KL: Oh yeah. Did you get finished?

Nigel: Yes. It's in the book, but someone has it.

KL: So people can borrow it from the binder to read it?

Nigel: [nods]

KL: Are you happy with the story?

Nigel: Yeah! [smiles]

Nigel then went on to tell me his friends had started a sign-up sheet for reading his story, pride evident in his voice. This excitement over his published piece took me by surprise. In our discussions, I did not often see Nigel smile when it came to the completion of assigned work. Up until this point in time he rarely, if ever, came close to making the set deadlines for handing work in to his teacher. His excitement generally was reserved for telling me about trips he had taken with his family, friends he played with, video games he enjoyed, new movies he had just acquired, or the luge track he created on the ramps of his building's underground parking garage.

From the point in time when the publication became public, Nigel began to see himself as capable of producing written work that entertained his classmates. This new identity seemed to remain with him as the rest of the year went on: at the end of the school year, Ms. Wynn described his penultimate piece as "very witty, creative." She added, 
It was punctual, it was on time. (...) It was interesting. I handed it back and I said, "Well done, Nigel." And he'd gotten 45 out of 45 or 45 out of 50 and he'd be like, "Yes!" And he'd be so excited because he'd earned it. (...) So I think he got a chance to experience what a high achiever gets to achieve. (Ms. Wynn)

\section{Discussion}

One of the advantages of using ANT (Latour, 2005) is that it allows for examinations of local interactions as they are mediated by global agents or sponsors. In this study, the teacher and students' interactions with literacy were framed by sponsors of literacy, distant and local, human and non-human, while simultaneously driven by their own personal agencies. For the teacher and students alike, enhancements and displacements to their literacy practices were evident as the traditionally framed writer's workshop was transformed in their classroom.

The writer's workshop was transformed in this classroom as several practices were overlaid on the traditionally framed social interaction: students engaged in a draft, revise, conference, revise, publish cycle, however, the practices differed substantially. Literacy objects were also added. Students received mini-lessons on writing, which, rather than being lessons directed to issues they collectively faced in their writing (as envisioned by Calkins, 1986), were mini-lessons lifted directly from a teacherpractitioner text, Notebook Know-How (Buckner, 2005). These mini-lessons were chosen with the intent of moving students to the next stage of the draft, revise, and publish cycle. The students produced drafts of stories they wanted to publish. The written feedback they received on these drafts consisted of their peers correcting spelling and grammar errors, not written feedback from their teacher. A class binder was introduced to hold student publications. A highlighted grading rubric, originally designed for summative feedback, took the place of traditional formative feedback in the form of annotations on student drafts. And finally, the posting of names on the "unfinished homework board" and the report card were other literacy objects called into action when large numbers of students failed to produce their first pieces for the classroom binder by the appointed date.

\section{Shifting Emphases}

In the layering-on of new practices in this classroom, the recursive cycle of process writing (draft-revise-conference-revise-conference-etc. until a piece of publishable quality is produced), as set out in a traditional writer's workshop, was altered. A highly linear and product-oriented focus resulted, driven by the requirement of having a piece published by a specified date.

As a sponsor of writing in her classroom, Ms. Wynn had certain objectives. The main objectives were to get students to write and to write quality pieces. But these objectives appear to have been displaced by pressures of managing a large and diverse classroom and fulfilling the requirements of assessment. To achieve this, literacy objects, particularly student publications and the writing rubric, were given increased responsibilities. In many ways, the onus for sponsoring writing in this classroom may be characterized as shifted from that which is predominantly provided by humans to writing sponsorship downloaded onto literacy objects. In this transformation, Ms. Wynn may be seen as working to satisfy the competing interests of two distant sponsors of literacy. 
While such agency may be applauded for reconciling the disparate interests to whom she must answer, this shifting of responsibility to literacy objects had consequences for students in the fifth grade class.

\section{Emphasizing Publication for Peers has Consequences for Student Authors}

Publication of their work for an audience of peers was viewed as a practice that would help students take responsibility for ensuring the writing they engaged in during writer's workshop was meaningful, structured and high quality. However, aspects of the students' engagement with the writer's workshop may have been displaced by mandatory student publication for an audience of peers. Knowing their audience, Nigel, Ally, and Sara placed certain boundaries on their own writing. These actions had implications for their social standing in the classroom. Both Sara and Ally were mindful of this audience and chose their topics carefully. Much of what excited or engaged them in their writing was displaced as they made their choices. Their decisions to develop for publication the horse story and the amusement park recount over other pieces indicated their deliberate intention to choose work that was safe for public consumption. Both girls clearly articulated their knowledge of the consequences associated with their work being made public but were able to retain some autonomy by choosing to publish stories of a different genre than their friends' publications.

For Nigel, however, a conflicting array of enhancement and displacement of literacy practice ensued through these interactions with publishing for his peers. On the one hand, Nigel moved into a place of agency as he authored a satirical story conveying a less than favourable impression of teachers and poking fun at the "Warnings" system used in his classroom, a system in which he regularly found himself implicated. Through the sponsorship of someone outside the classroom and the mediational activity associated with literacy objects, particularly his student publication, Nigel was enabled to regain some of the agency the requirements of grade five seemed to have stripped from him. By publishing a piece, in the first person voice, about gaining victory over a teacher he felt to be dishonest, Nigel not only became more popular amongst his peers when other students lined up to read his work; he also seemed to rhetorically recover a lost sense of agency as he realized his ability to entertain peers through his writing. However, the intertextual links Nigel was forming between his recreational practices, his reading, and his writing when he drafted his initial piece, Sled Ride, were displaced through his mother's intervention. Nigel may have inadvertently been given the message that relying on his own resources for writing a story of publishable quality was not advisable and that instead he would be better served relying on the ideas of another.

\section{Layering Report Card Grades onto Publishing for Peers has Further Consequences}

When she stated, "...if you give students an audience, other than teachers, their writing samples go way up. Their expectations on themselves go way up because they know their friends are going to be reading it", Ms. Wynn expressed the expectation that publication of their stories for an audience of their peers would not only help students to write more but would help them to write higher quality pieces. However, for Sara, Ally and Nigel writing a piece that was to be graded while keeping an audience of their peers in mind had implications Ms. Wynn may not have envisioned. 
In the rendition of writer's workshop in place in their classroom, these students had two distinct types of audience with which to concern themselves: their peers and their teacher. Nigel wrote My Teacher Is a Snowman at home, using a story starter prompt book and his mother as editor. The shifting of responsibility for sponsoring writing instruction onto literacy objects in his classroom failed to move Nigel toward successfully producing work for publication. Producing work that would be graded for his report card was required of him; however, his lack of interest in this new system, not absence of ability, put him in danger of academic failure. The report card, as a literacy object, held little sway over Nigel. It was the sponsorship of his mother and her introduction of another literacy object, a story starter flip book, which helped Nigel change course. Nigel did not anticipate negative reception of his piece from peers or his teacher. In fact, he was more concerned with writing a piece that met his own requirements of providing entertainment than ensuring he would not receive a poor mark for the writing portion of his language arts grade. Because another human sponsor, his mother with the story starter book, stepped in to help him mediate the dual responsibilities associated with two audiences - quality and punctuality for the teacheras-assessor audience, entertainment for the peer audience - Nigel was successful with both audiences.

Whether it was a concern for her peers' response to her horse story or her desire to conform to the injunction by her teacher to be sure to have a story published by a set date, Sara seemed unaware of the summative assessment that would take place once her work was made public. This put Sara in a precarious position. Her social positioning was mediated by the requirement that her writing be publicized. Furthermore, because of social concerns related to paying attention to her peer audience and showing herself to be a responsible, independent student, it is possible she may not have published her best piece or developed her most interesting ideas into finished pieces. These concerns may also have worked to compromise her academic positioning.

Ally's interest in writing about ideas that had emotional import for her was clearly displaced by concern about audience reaction. How this concern about peer ridicule might mitigate the passion with which she writes in the future now becomes a serious point for consideration.

\section{Implications}

The practice of students' writing for an audience other than their teacher was an early and important feature of writer's workshops as set out by early sponsors of the children as writers' movement (Calkins, 1986; Graves, 1983, 2003; Langer \& Applebee, 1987). And it is one that has endured for three decades as it continues to be practiced in countless contemporary classrooms. However, those who sponsor it in local classrooms must handle it in a nuanced manner. While producing "publishable" pieces by set dates may be necessary requirements in an accountability era, student publication for peers cannot necessarily be adopted as a singular goal that benefits all students. Furthermore, the manner by which students arrive at those publications must also be treated with flexibility. While structured procedures may give the impression of guiding students toward more productive writing, when they are too narrowly constructed or too tightly held, individual students' needs may well go unmet. Enhancement of literacy practice may occur for some aspects of students' writing, however, the displacement a singular 
focus on publication for peer audiences that ensues for others must receive equal consideration.

The fifth grade at Howe River elementary school is not unique. Throughout Western nations, where standards-based education is the norm and the curriculum full, teachers must make decisions about how they will meet the mandates of curriculum and assessment. How many other classrooms are there in which teachers, whose teaching practices are mediated by a host of influences, rely heavily on literacy objects to serve as surrogates for themselves in teaching and assessment? The convenience or efficiency of relying on literacy objects to teach and assess may be enticing. However, the teacher's role in mediating the alienating potential and displacement of personal literacy practices that graded publications for peer audiences may have for some students, is one that cannot be neglected.

\section{Concluding Thoughts}

In this classroom, writer's workshop was viewed as a valuable means for motivating students to write. However, the focus radically shifted from the processoriented practices of writer's workshop promoted in the majority of pedagogical literature on the subject. By shifting the emphasis to the final literacy objects of writer's workshop (student publication, the grading rubric, and the report card), the potential for students to hone their writing through the practices of drafting and receiving regular feedback from peers and teachers was displaced.

Innovations to time-honoured pedagogies, such as writer's workshop, should always be undertaken in order to provide instruction that both fits local contexts and meet more globally located mandates. However, tremendous care must be taken by educators to analyze the meanings individual students take away from the process. The question that must inform all practices localized in the classroom writer's workshop is one of how we might create flexible procedures and safe spaces for all students to publish their work, so that all young writers may experience its potential benefits.

\section{References}

Atwell, N. (1987). In the middle: Writing, reading, and learning with adolescents. Upper Montclair, NJ: Boynton/Cook Publishers.

Barton, D., Hamilton, M., \& Ivanic, R. (2000). Situated literacies: Reading and writing in context. London, UK: Routledge.

Barton, D., \& Hamilton, M. (2005). Literacy, reification, and the dynamics of social interaction. In D. Barton \& K. Tusting (Eds.), Beyond communities of practice: Language, power and social context. Cambridge, UK: Cambridge University Press.Baynham, M., \& Prinsloo, M. (2009). The future of literacy studies. New York, NY: Palgrave Macmillan.

British Columbia Ministry of Education. (2002). British Columbia performance standards: Writing. Province of British Columbia.

British Columbia Ministry of Education. (2006). English Language Arts grade 5: Integrated resource package 2006. Province of British Columbia.

Brandt, D., \& Clinton, K. (2002). Limits of the local: Expanding perspectives on literacy as a social practice. Journal of Literacy Research, 34(3), 337-356. 
Buckner, A. (2005). Notebook know-how: Strategies for the writer's notebook. Portland, ME: Stenhouse Publishers.

Calkins, L. M. (1986). The art of teaching writing. Portsmouth, NH: Heinemann.

Calkins, L. M. (1994). The art of teaching writing (2nd ed.). Portsmouth, NH: Heinemann.

Collins, J., \& Blot, R. K. (2003). Literacy and literacies: Texts, power, and identity. Cambridge, UK: Cambridge University Press.

Fletcher, R., \& Portalupi, J. (1998). Craft lessons: Teaching writing $k$ - 8. New York, NY: 1998.

Graves, D. (1983). Writing: Teachers and children at work (1st ed.). Portsmouth, NH: Heinemann.

Graves, D. (2003). Writing: Teachers and children at work (2nd ed.). Portsmouth, NH: Heinemann.

Hamilton, M. (2001). Privileged literacies: Policy, institutional process and the life of the IALS. Language and Education, 15(2 \& 3), 178-196.

Heath, S. B. (1983). Ways with Words. Cambridge, UK: Cambridge University Press.

Hoffman, J. V. (1998). When bad things happen to good ideas in literacy education: Professional dilemmas, personal decisions, and political traps. Reading Teacher, 52(2), 102.

Langer, J., \& Applebee, A. (1987). How writing shapes thinking: A study of teaching and learning. Urbana, IL: National Council of Teachers of English.

Latour, B. (1994). On technical mediation - philosophy, sociology, genealogy. Common Knowledge, 3(2), 29-64.

Latour, B. (1996). On interobjectivity. Mind, Culture, and Activity: An International Journal, 3(4), 228-245.

Latour, B. (2005). Reassembling the social: An introduction to actor-network-theory. New York, NY: Oxford University Press.

Lensmire, T. (1994). Writing workshop as carnival: Reflections on an alternative learning environment. Harvard Educational Review, 64(4), 371-391.

Lewis, C., Enciso, P., \& Moje, E. B. (Eds.). (2007). Reframing sociocultural research on literacy. Mahwah, NJ: Lawrence Erlbaum.

Lipson, M. Y., Mosenthal, J., Daniels, P., \& Woodside-Jiron, H. (2000). Process writing in the classrooms of eleven fifth-grade teachers with different orientations to teaching and learning. Elementary School Journal, 101(2), 209.

Murray, D. (1980). Writing as process: How writing finds its own meaning. In T. R. Donovan \& B. W. McClelland (Eds.), Eight approaches to teaching composition pp. 3-20. Urbana, IL: National Council of Teachers of English.

Pahl, K., \& Rowsell, J. (Eds.). (2006). Travel notes from the new literacy studies. Clevedon, UK: Multilingual Matters.

Ray, K. W. (1996). Wondrous words. Urbana, IL: National Council of Teachers of English Press.

Scollon, R., \& Scollon, S. (1981). Narrative, literacy, and face in interethnic communication. Norwood, NJ: Ablex.

Scribner, S., \& Cole, M. (1981). The psychology of literacy. Cambridge, MA: Harvard University Press.

Smith, F. (1988). Understanding reading (4th ed.). Hillsdale, NJ: Lawrence Erlbaum. 
Street, B. V. (1993). Cross-cultural approaches to literacy. New York, NY: Cambridge University Press.

Street, B. V. (2003). What's "new" in the new literacy studies? Critical approaches to literacy and practice. Current Issues in Comparative Education, 5(2), 1-14.

\section{Author Biography}

Kimberly Lenters is an assistant professor in the Faculty of Education at the University of Calgary. Her work focuses primarily on ways in which sociocultural perspectives of literacy may be utilized to understand and enhance the in-school and out-of-school literacy development of elementary school students. 